\title{
Hizb'allahs råderum i transnationale shia islamiske magtstrukturer
}

\author{
Af Rune Friberg Lyme \\ Resumé \\ Lige siden Hizb' allah første gang fandt vej til alverdens forsider for et kvart århundrede siden, har \\ den Islamiske Republik Iran og ayat'allah Muhammed Hussein Fadlallahs indflydelse på organi- \\ sationen været genstand for megen debat. Artiklen foreslår, at en diskursanalytisk og kritisk di- \\ skursanalytisk forståelse af religiøse magtstrukturer kan være med til at nuancere forståelsen af \\ Hizb'allahs aktørråderum og relationskomplekser. Der argumenteres således for, at organisatio- \\ nen er underlagt wali al-faqihs autoritet, men i de senere år har udviklet stadig større frihedsgra- \\ der. I udfyldelsen heraf har marja al-taqlid Muhammed Hussein Fadlallah været en vigtig inspira- \\ tionskilde, om end organisationen officielt følger Ali al-Khamenis marjaiyyat. Som konsekvens \\ har organisationens medlemmers hverdag på mange områder været mere præget af maraji al- \\ taqlid, Ali al-Sistani og afdøde Muhammed Hussein Fadlallah end af Ali al-Khamenei.
}

Libanesiske Hizb'allah har i løbet af sin godt tre årtier lange eksistens udviklet sig til verdens mest indflydelsesrige shiaislamiske ikke-statslige organisation. Siden revolutionsgardister og diplomater fra den Islamiske Republik Iran i 1982 samlede, finansierede, trænede og udrustede en broget flok af libanesiske ulama, gejstlige, og modstandsorganisationer i det $\varnothing$ stlige Libanons Beqaadal i den paraplyorganisation, som skulle blive kendt som Hizb'allah, har et tilbagevendende tema i det omfattende korpus af litteratur på området været, hvem der i sidste ende trækker i trådene i organisationens alsidige og omfattende virke. En dominerende tilgang både i forskningen og i medierne har været, at Hizb'allah groft sagt fungerede som en forlænget arm for det Iran, som siden organisationens etablering rundhåndet har leveret blandt andet finansiel, efterretningsmæssig, militær og politisk støtte. Hizb’allah har da heller aldrig selv lagt skjul på de særdeles tætte bånd til den islamiske republik (jf. eks. Qassem 2005:235-239, Alagha 2007:172). Samtidig har megen opmærksomhed samlet sig om Libanons højestrangerende shiitiske alim, ental af ulama, Muhammed Hussein Fadlallah, der i en alder af 74 år den 4. juli 2010 sov ind på Bahman hospitalet i Harat Hreik, en af Beiruts sydlige forstæder. Den indflydelsesrige ayat'allah, Guds tegn, der fungerede som en væsentlig drivkraft og et omdrejningspunkt i det (såvel sunni som shia) islamiske miljø i Libanon, blev af mange observatører betragtet som Hizb’allahs murshid ruhi, religiøse leder, eller med den amerikanske Hizb'allahforsker Martin Kramers ord the Oracle of Hizbullah (Kramer 1997, se endvidere Ranstorp 1997:37, 42, Almond, Sivan og Scott Appleby 1995:141, Piscatori, 2000:27). Alt for sjældent er der dog blevet stillet spørgsmålstegn ved, hvordan Hizb'allah skulle 
kunne fungere som forlænget arm for det teokratiske styre i Iran og på samme tid være underlagt en religiøs leder, som i mere end ti år havde så betændte forbindelser til det iranske regime, at parterne ikke var på talefod (Shaery-Eisenlohr 2008: 144, Sankari 2005: 267, Chehabi 2006b: 300). Paradokset indikerer den store kompleksitet i Hizb'allahs relationer. Inddragelse af og forøget opmærksomhed om religiøse faktorer har dog i nyere forskning vist sig frugtbar i bestræbelserne på at forstå Hizb'allahs komplekse relationsstrukturer og hjælpe til at identificere nogle af de mekanismer, der strukturerer og omformer forholdet mellem parterne og deres betydning for organisationen (se eksempelvis Saad-Ghorayeb, 2002, Harb og Leenders, 2005, Hamzeh, 2004, Alagha, 2006). I de senere år har man i litteraturen i stigende grad fået øjnene op for betydningen af Hizb'allahs accept af ayat'allah Ruhollah al-Mussawi Khomeinis religiøse ideologi indenfor usuli skolen i den ithna'ashari shiitiske tradition, velayat e-faqih, Juristens (i religiøs jura, fiqh) formynderskab/vejlederskab, eller på arabisk wilayat al-faqih. Ali Akbar Mohtashami, der spillede en vital instrumentel rolle i etableringen af Hizb'allah som iransk ambassadør i Syrien (der i 1982 kontrollerede blandt andet den libanesiske Beqaadal), kaldte meget sigende i 2006 Hizb'allah for Imam Khomeini og den islamiske revolutions spirituelle afkom (Minoui 2008: 89). Mange af organisationens grundlæggere havde ved de religiøse akademier i Najaf været en del af den samme aktivistiske religiøse bevægelse, som Khomeini var vokset ud af. Udover at knytte tætte familiære og venskabelige bånd, udveksledes religiøse ideologier og ideer på tværs af nationaliteter og landegrænser. Ligesom mange iranere - heriblandt Khomeinis to sønner - før revolutionen trænede i Libanon, var en række libanesiske shiiter engageret i støttekomiteer og frivillige brigader til den iranske revolution (Alagha 2006: 28, Mervin 2008: 78, Chehabi 2006: 203). Som sådan så mange libanesiske islamister sig selv som en direkte forlængelse af den islamiske revolution. Khomeinis wilayat al-faqih, der fire år tidligere havde fungeret som ideologisk blueprint for den nye islamiske republik i Iran, blev således også én af blot tre punkter, som libanesiske islamister og modstandsorganisationer i 1982 lagde til grund for det senere Hizb'allah - de to øvrige værende en islamisk identitet og væbnet modstand mod Israel som led i jihad, stræben i og for Guds vej (Qassem 2005:19). Lige siden har wilayat al-faqih fungeret som ideologisk hjørnesten for organisationen og dermed accepteret wali al-faqihs, den juridiske formynders, religiøse autoritet. Wali al-faqih 
er dog ikke den eneste religiøse autoritet, som Hizb'allah anerkender. Også den traditionelle institution i den shiitiske tradition, marjayyia at-taqlid, kilde til efterlevelse, spiller en afgørende rolle for Hizb'allah. Men hvilken betydning har det så for Hizb'allah og organisationens medlemmer at acceptere disse religiøse autoriteter? Det er netop omdrejningspunktet for nærværende artikel. På baggrund af en analytisk forståelse af religiøse magtstrukturer i organisationens religiøse ideologi vil denne tekst således forsøge at nuancere forståelsen af Hizb'allahs aktørråderum og organisationens forhold til og påvirkning fra eksterne religiøse autoriteter.

Undersøgelsen vil finde sted i tre etaper. Indledningsvis opridses en analytisk forståelsesoptik af religiøse magtstrukturer og deres betydning for de involverede aktører med afsæt i diskursanalytisk og kritisk diskursanalytisk tankegods. Efterfølgende vendes blikket mod Hizb'allah med en redegørelse af de primære magtstrukturelle karakteristika i organisationens religiøse diskurs. På den baggrund analyseres de religiøse magtstrukturers betydning for organisationens råderum og relationer til religiøse magtinstitutioner.

\section{Analytisk ramme: Religion som diskursiv kategori}

Historically, what exists is the church. Faith, what is that? Religion is a political force (Foucault i Carrette 1999:107)

Religion bliver i denne tekst forstået som en generisk diskursiv kategori i et poststrukturalistisk spor baseret på diskursanalytiske og kritisk diskursanalytiske forståelser. ${ }^{1}$ I dette perspektiv tildeles religion som diskurs tre overordnede funktioner. Religion menes således at have en ideationel eller meningsskabende funktion, idet de religiøse diskurser konstruerer systemer af viden og overbevisning. Den fungerer tillige relationsskabende, da der i diskurserne konstrueres og organiseres sociale relationer mellem folk. Endeligt er religionen identitetsskabende, da sociale identiteter konstrueres i diskurserne (Laclau \& Mouffe 2001 [1985]:96, Fairclough 1992:64, 1995: 6, 1995b:55). ${ }^{2}$ Sidstnævnte funktion er det kritiske diskursanalytiske bidrag - med Fairclough i spidsen - qua tilgangens fokus på, hvordan diskursive praksisser bidrager til at skabe og reproducere magtforhold mellem sociale aktører. Her betones diskursernes (i Norman Faircloughs terminologi benævnt ideologier) produktion og reproduktion som funktion af sociale magtrelationer gennem hegemoniske kampe, som placerer aktører i partikulære dominansrelationer, der 
reproduceres og transformeres qua den kontinuerlige italesættelse (Fairclough 1995:17,76, Heather 2000:33). Som sådan betragtes religion altså ikke som et sui generis fænomen, men som en social praksis, der af natur sidestilles med andre diskursive kategorier, blot konstitueret med meningsbetydninger, som vi kategoriserer som religiøse, eksempelvis overjordiske autoriteter, distinkte eskatologiske opfattelser og opfattelser af belønninger og straf i det hinsides. Selvom det derfor vil mere dækkende at tale om diskurser med religiøse karakteristika, vil betegnelserne religion og religiøse diskurser blive anvendt i det følgende for læsevenlighedens skyld.

Religiøse diskurser indebærer - som alle andre diskurser - meningsudfyldelsen af et kontekstuelt bestemt felt og med et distinkt, diskurskontekstuelt indhold, men vil - som diskurs - være ustabil, foranderlig og genstand for kontinuerlig debat og redefinering og hegemonisk konkurrence med andre diskurser. Nogle religiøse diskurser er - i konkurrencen med andre diskurskategorier - forvist til at meningsudfylde en begrænset del af sine subjekters hverdagsvirkelighed af sociale relationer, begreber og sprog - her er det oplagt at pege på den dominerende religiøse diskurs i den danske folkekirke -, mens andre gør krav på at være altomfattende, således at hele den sociale virkelighed skal meningsudfyldes på baggrund af og i forhold til den viden, der eksisterer i den religiøse diskurs. Hvad religion som kategori udgøres af og hvor grænserne går, defineres og redefineres altså konstant af de sociale og historiske kontekster af det sociale menneskelige liv (Asad, u.d, Carrette 2000:146). Det har den umiddelbare konsekvens, at det ikke giver analytisk mening at snakke om rigtig eller forkert religion, eller om et a priori skel mellem religion og politik. Tilsvarende vil udtrykket for religiøs retledning - eksempelvis gennem ortopraksis eller ortodoksi - bestemmes i den konkrete religion. Til forskel fra primordiale og instrumentelle tilgange til religion vil man altså i dette perspektiv hævde, at religion er, hvad den konkrete religions subjekter gør den til. I relation til Hizb'allah betyder det i al sin enkelhed, at man som analytiker må arbejde på baggrund af netop den specifikke religiøse opfattelse og dens legitimitetsområde, som organisationen selv italesætter.

Religionens diskursfunktioner indebærer, at den religiøse diskurs' viden fremstår som the ensemble of rules according to which the true and false are separated for diskursens subjekter (Foucault 1980a:132, jf. endvidere Carrette 1999:32). Viden om sociale sammenhænge og verdensforståelser bliver defineret i selve diskursen - religionen - således at 
subjekter, der arbejder indenfor og på baggrund af denne, vil trække på fortolkning af hændelser og handlemuligheder meningsudfyldt i forhold til den diskursive viden. Med andre ord kan religionen fundamentalt forme opfattelsen af selve den sociale verden, som folk opfatter og handler meningsfyldt i forhold til. Verdens kosmologi, aktørers målsætninger og identiteter, konstruktioner af relationer til venner og fjender, hvad der er tilladt og hvad der ikke er - alt sammen henter det mening i religionen. En religiøs diskurs kan på den måde give en mening til den verden, som subjektet oplever sig en del af, subjektets opfattelse af egenidentitet, $\emptyset$ vrige sociale aktørers identiteter og relationen til disse samt handlingsanvisninger - hvis den konstant foranderlige religiøse diskurs vel at mærke er meningsfikseret med et krav om at skulle meningsudfylde disse felter.

Det leder til relationerne mellem de forskellige subjekter, der arbejder indenfor diskursen samt deres adgang til at reformulere religionen og dermed også den deri indlejrede viden. Den religiøse diskurs' meningsfiksering af sociale relationer mellem aktører og disses identiteter involverer således også positionering af aktører i partikulære dominansrelationer. Den diskurskonstruerede viden kan involvere formulering og omformulering af sociale hierarkier blandt aktører, eller mere præcist, aktørpositioner. Et eksempel vil være mellem lægmand/troende og præster, imamer, skriftefædre, paven etc. Magtstrukturerne vil dog gerne være mere komplekse eller med Foucaults ord, indebære a multiform production of relations of domination (Foucault 1980b: 142). For at opnå mening må relationen mellem aktører meningsfikseres i forhold til den $\emptyset$ vrige diskursive viden om eksempelvis kosmologi, eskatologi, målsætninger og handlingsanvisninger. Et oplagt eksempel er den katolske kirkes legitimering med reference til Jesu ord om Peter som den klippe, at han vil bygge sin kirke på i Matthæusevangeliet 16:18. I dette perspektiv bør en religions institutionelle set up - kirken, om man vil - ikke betragtes som eksogen af religionen, men i høj grad en endogen del af den religiøse diskurs eller religionen. En sådan religiøs magtstruktur indebærer differentieret adgang til redefinering af religionen. Dette kan umiddelbart synes at modstride den diskursteoretiske forståelse af, at ethvert subjekt har ligelig vægt i den konstante artikulation og reartikulation af diskursen. Alle har de den samme vægt, når det kommer til at producere og reproducere religionen, da de alle er subjekter til samme diskurs. Diskursen eksisterer som sådan kun fordi alle subjekterne konstant italesætter og gen-italesætter den, inklusive de indbyggede magtstrukturer. Ikke 
desto mindre kan aktørpositionerne i de dominansrelationer, der er indlejret i de religiøse diskurser, også kan være konstitueret med diskursspecifikke sociale identiteter, der har asymmetrisk priviligering i forhold til den religiøse diskurs' redefinering. ${ }^{3}$ Med andre ord, så kan religionen tildele specifikke aktørpositioner differentieret adgang til eksempelvis at fortolke, hvad der er religiøst retledet i en given situation, således at disse i sidste ende får privilegeret indflydelse på, hvordan religionen ser ud. Hvis nogle positioner eksempelvis shamaner, præster etc. - meningsfikseres med særlige rettigheder til eller forudsætninger for at forstå og fortolke Guds ord, finder en sådan differentiering sted. Idet alle religiøse diskurser - som alle andre diskurser - vil være partikulære, vil det uundgåeligt betyde, at forskellige religiøse diskurser har distinkte magtstrukturer med forskellige potentielle asymmetrier i aktørernes adgang til reartikulation af religionen. De privilegerede aktørers position i relation til andre subjekter samt deres adgang til at italesætte verdensbillede, venne-fjenderelationer og det religiøst tilladte og forbudte, vil derfor afhænge af og blive defineret i den enkelte religiøse diskurs. Med andre ord, hvad det vil sige at være en 'religiøs leder' altså afhænge af den konkrete religiøse diskurs. Ligeledes vil øvrige aktører - være det sig organisationer eller individer - få deres agency, råde- og handlerum indenfor det sociale felt, som den aktuelle diskurs meningsudfylder, defineret i den diskurs, som de beror på. For en aktør, der er subjekt til en religiøs diskurs, kan det altså betyde, at aktørens eget råderum til at fortolke, italesætte aktører, begivenheder og redskaber, er meningsfikseret i den konkrete diskurs' magtstrukturer.

Idet den religiøse diskurs er foranderlig, vil også de indlejrede magtstrukturer være genstand for løbende forandring over tid. Denne forandring vil være underlagt den konstante overordnede udfordring af diskursen fra andre diskurser, samtlige subjekters artikulation og reartikulation vil samtidig være underlagt aktørernes differentierede adgang til at reartikulere religionen samt meningsfikseringen i forhold til den $\emptyset$ vrige religiøse diskursive formation. Aktører, der er italesat i privilegerede positioner, kan således meget vel også være dem, der har privilegeret adgang til at reartikulere magtstrukturer, hvor transformationen legitimeres med reference til allerede kendte religiøse begreber.

Med afsæt i diskursanalytisk og kritisk diskursanalytisk tankegods kan man altså opnå en opmærksomhed på, at religioner indlejrer diskursspecifikke partikulære magtstrukturer i hvilke aktørpositioner er relationelt positioneret med potentielt asymmetrisk adgang til at 
definere og redefinere religionen. Som endogene til den religiøse diskurs er magtstrukturerne meningsfikserede i forhold til og på baggrund af den diskursive religiøse viden den religiøse mytologi, kosmologi og eskatologi - og derfor også foranderlig over tid.

\section{Metodiske overvejelser}

En forståelse af hvordan en aktør, der er subjekt til en given religiøs diskurs, bliver påvirket af de religiøse magtstrukturer kræver, at man går ned af ikke ofte trådte analytiske stier. I den traditionelle diskursanalyse er det analytikerens opgave at indkredse diskursen eller, om man vil, identificere arkivet, der regulerer, hvad der er blevet sagt og ikke sagt i et givent samfund. I den kritiske diskursanalyse er målsætningen i stedet at identificere eksisterende dominansstrukturer i diskurserne. Denne tekst vil forsøge at gå et skridt videre ved, gennem en optik bestående af den ovenfor præsenterede religionsforståelse, deduktivt at forsøge at forstå, hvorledes magtstrukturer indlejret i Hizb'allahs diskurs påvirker organisationens handlerum og med hvilket resultat.

Hizb'allah behandles som en enhedsaktør og i analytisk forstand et enhedssubjekt. Man har tidligere oplevet enkelte åbne kontroverser om religiøs legitimitet indenfor organisationens egne rækker, men generelt har organisationen fremstået særdeles uniform. ${ }^{4}$

Undersøgelsen vil finde sted i to trin. Indledningsvis vil relevante magtstrukturer i den religiøse diskurs, som Hizb'allah beror på, blive identificeret og forklaret. Efterfølgende vil med afsæt i ovennævnte religionsforståelse blive analyseret, hvilken indvirkning det har og har haft på Hizb’allah på baggrund af den historiske udvikling, udtalelser de historiske udvikling som de magtstrukturer har resulteret i, blive undersøgt. Med andre ord vurderes ikke blot på retoriske strukturer, men også de handlinger som er fulgt, givet en forhåndsforståelse af, at disse har været meningsudfyldt i forhold til den religiøse diskurs og som sådan er produkter heraf. Derfor anvendes et langt bredere materiale end en diskursanalyse bygger på. Således vil det i høj grad hvilke handlinger, som aktørpositionen har manifesteret sig i. 


\section{Signifikante magtstrukturer i Hizb'allahs religiøse diskurs}

Den religiøse diskurs, som Hizb'allah er med til at producere og reproducere, hævdes altomfattende legitimitet. Som Hizb'allahs tidligere ansvarlige for internationale relationer og nuværende parlamentsmedlem Nawaf al-Mussawi for nogle år siden forklarede denne forfatter: Islams ånd er altomfattende og inkluderer alle aspekter af livet (Mussawi, int.). Det er naturligvis ikke overraskende, at Hizb'allah som islamisk organisation hævder dette, men det betyder, at organisationen må forstås som fuldt impliceret i den religiøse diskurs. Ikke alene beror Hizb'allah i sin subjekt opfattelse på den religiøse diskurs, men denne tildeles samtidig primat, således at andre diskurser som Hizb'allah forholder sig til, også skal hente mening i forhold til den religiøse diskurs, som organisationen hævder, skal meningsudfylde alle aspekter af det sociale liv. Hvad enten der er tale om politik, rituelle praksisser, gennemførelse af væbnede handlinger eller familieforhold, må disse derfor meningsfikseres i og på baggrund af den religiøse diskurs. Den konkrete religiøse diskurs fungerer dermed som begrebsapparatet, som Hizb'allah trækker på i sin meningsfiksering og fortolkning af den sociale virkelighed. Alle argumenter, aktiviteter og vurderinger må artikuleres i forhold til den religiøse diskurs’ nodalpunkter og øvrige meningsfikserede indhold for at give mening og hente legitimitet. Organisationen trækker således på den religiøse kosmologi, mytologi og eskatologi i sin italesættelse af verdens begivenheder og aktører. Verden hævdes at være organiseret omkring en bipolær kosmisk konflikt mellem det sataniske og det rette, der vil vare frem til Dommedag og gennemsyrer alle sociale niveauer fra international politik, krig og fred til den det enkelte menneskes hverdagsproblemer og dagligliv. ${ }^{5}$ I denne konflikt hævdes Gud at have pålagt mennesket pligt til at yde modstand og opretholde et irrekonsibelt konfliktuelt, khilaf, forhold til det onde, en pligt, hvis opfyldelse vil føre til en belønning for den enkelte i det hinsides (eks. Nasrallah 24.4.2000, 17.11.2003, Qassem, 2005:35) og for fællesskabet i det jordiske. ${ }^{6}$ På den baggrund kan i Hizb'allahs retorik identificeres fire aktørpositioner, som organisationen inddeler og vurderer alle aktører i den jordiske verden. ${ }^{7}$ Enkelte jordiske aktører artikuleres som jordiske manifestationer af Satan og dermed immanent og uforanderligt undertrykkende og onde. ${ }^{8}$ Alle andre end de jordiske materialiseringer af den sataniske ondskab konstitueres med muligheden for at vælge mellem det rette og det onde strid eller konflikt, ikhtilaf. ${ }^{9}$ Ikhtilaf adskiller sig fundamentalt fra khilaf. I modsæt- 
ning til det irrekonsible forhold, khilaf, som de retledede skal opretholde, giver ikhtilaf nemlig mulighed for fredelig sameksistens og et harmonisk forhold med de retledede (Saad-Ghorayeb 2002:108).

Ligeledes må rammer for handlingsanvisninger være baseret på og finde mening i forhold til den religiøse diskurs. For Hizb'allahs vedkommende gælder, at jihad, at stræbe i og for Guds vej, og overkomme de medfølgende vanskeligheder, fremstilles som selve forudsætningen for det religiøst retledede liv. ${ }^{10}$ Jihad er ikke desto mindre en alsidig affære med syv differentierede modaliteter, der fremstilles som uløseligt forbundne og gensidigt afhængige (Khashan og Moussawi, 2007). ${ }^{11}$ Således bindes anvendelse af våben, herunder martyrmissioner/selvmordsbombere, organisk og uløseligt sammen med socialt arbejde og politisk deltagelse. I den religiøse diskurs må disse aktiviteter hente mening $\mathrm{i}$ forhold til den religiøse mytologi. Et vitalt nodalpunkt for meningsfikseringen af jihad har således været den ufejlbarlige Imam Husseins martyrium i kamp mod Umayyadleders Yazeeds overtallige tropper i Karbala i år 680. Som den hyppige recitering af Khomeinis gamle slogan: Hver dag er ashura og alle steder er Karbala understreger, trækkes lige linjer mellem den religiøse mytologi og den umiddelbare hverdag (Alagha 2006:107). Men som generalsekretær Nasrallah videre forklarer: Gud kan ikke adlydes ved ikke at adlyde Ham (Nasrallah 8.11.2003, jf. Mussawi, int.). Ordene henfører til de stramme regler for, hvordan jihad må udføres. Jihad indebærer nemlig ikke blot at stræbe eller kæmpe for Guds vej. Jihad forudsætter også, at denne stræben sker $i$ Guds vej. Målet helliger i sig selv ikke midlet, men er underlagt en række begrænsninger, som findes i den religiøse diskurs. ${ }^{12}$ Det betyder, at anvendte midler skal kunne retfærdiggøres i forhold til de i den religiøse diskurs opstillede præmisser.

I artikulationen af Hizb'allahs verdensbillede og handlingsanvisninger spiller de religiøse magtstrukturer en afgørende rolle. To sådanne, delvist overlappende strukturer er af vital betydning for Hizb'allah, nemlig de strukturer, der resulterer af henholdsvis marjaiyya at-taqlid og wilayat al-faqih.

Marjayyia at-taqlid al-mutlaq, øverste kilde til efterlevelse, kan som religiøs institution dateres tilbage til midten af det attende århundrede, men fremkomsten af massemedier har medført, at den religiøse magtstruktur har udviklet sig markant op gennem det tyven- 
de århundrede (Rosiny 2007). Marjayyia at-taqlid er bygget op om to grundideer. Den første er praktiseringen af ijtihad, hvilket vil sige rationel deduktion på baggrund af de religiøse kilder såsom Quran og hadith. Ijtihad praksissen er italesat i forhold til den shiitiske mytologi med en rodfæstning i opfattelsen af, at mennesket - på grund af sin egen fejlbarlighed - på ethvert givent tidspunkt skal efterleve anvisningerne fra de ufejlbarlige Imamer, der som efterkommere af Profeten menes at have fuldstændig og ufejlbarlig indsigt i Guds vilje (Al-Mussawi, int., Khuri 1990). Alene herved kan mennesket sikre, at det lever i overensstemmelse med den religiøse retledning, som Gud ønsker af mennesket. Lige siden den tolvte Imam forsvandt endelig i okkultation, ghayba al-kubra, i år 941 har mennesket været afskåret fra umedieret adgang til imamernes ufejlbarlige vejledning. På den mytologiske baggrund argumenteres indenfor usuli skolen for, at man må identificere nogle principper, usul al-figh, til at udlede de islamiske regler med udgangspunkt i de religiøse skrifter. Hvordan man rent praktisk skal overføre principperne for, hvad der er religiøst retledet i den moderne verden, forudsætter rationaliseringen, ijtihad, over hvordan principperne skal gennemføres i den aktuelle virkelighed. Hvad der er retledet, skal hele tiden vurderes i forhold til samtiden. Det er dog langtfra alle, der tildeles ret til at foretage ijtihad. Det hævdes nemlig at kræve et meget højt niveau af viden og forståelse af de religiøse skrifter og deres applicerbarhed, som kræver gerne 20-25 års avancerede religiøse studier (uden at man derved er selvskreven) (Abisaab 2006: 249250). De få personer, der opnår den fornødne indsigt, kaldes mujtahid.

Det andet rationale, som marjaiyya al-taqlid involverer, ligger i snæver forlængelse af den første, nemlig at de mange mennesker, som ikke besidder den nødvendige indsigt i religionen, i stedet må efterleve og følge mujtahids vurdering og eksempel for at sikre deres religiøse retledning, hvilket kaldes taqlid. De folk, der efterlever mujtahids vurderinger, kaldes muqallideen, de der imiterer, i flertal og muqallid i ental (jf. SaadGhorayeb 2002:60, ICG 2005:20, Fayyad, int.). Der er dog den vigtige forskel på vejledningen fra henholdsvis Imamerne og mujtahid, at sidstnævnte ikke regnes for ufejlbarlige, idet de ikke har fuldstændig indsigt i Guds planer. Hvor Imamerne altså per definition er fejlfri i sine religiøse vurderinger, kan mujtahid potentielt set tage fejl. Tilsammen indebærer taqlid og ijtihad, at der etableres en relationel magtstruktur mellem mujtahid og muqallideen, hvor mujtahid - i Imam al-Mahdis fravær - har til opgave og ansvar for at 
sikre, at almindelige mennesker, muqallideen, lever i overensstemmelse med de religiøse bud på ethvert givent tidspunkt ved at foretage kvalificerede, rationelle vurderinger af, hvad der er religiøst korrekt i nutiden, når nu disse ikke forhold ikke er direkte beskrevet i de religiøse kilder. Dermed er selve mujtahid-positionen konstitueret med en mere privilegeret adgang til formuleringen af den religiøse diskurs end muqallideen, men samtidig betyder fejlbarligheden, at der er plads til forskellige vurderinger af den religiøse retledning.

I tilgift til relationsstrukturen mellem mujtahid og muqalideen findes der internt blandt mujtahids et uformelt hierarki, hvor de mest lærde mujtahid betragtes som maraji attaqlid, autoritative kilder til efterlevelse, en anerkendelse der er de allerfærreste forundt. Qua sin store (om ikke ufejlbarlige) forståelse af Guds vilje menes en sådan marja, ental af maraji, at fungere som et fyrtårn for almindelige menneskers, og andre lavere rangerende mujtahids, bestræbelser på at holde sig på den snævre sti af religiøst retledning. For at leve op til det, skal en marja ideelt set kombinere en unik forståelse af religiøs lærdom og ræsonnement med en personlig fromhed, overbevisning og retfærdig karakter (Walbridge, 2001). Ideelt set burde der i teorien blot eksistere én ultimativ marja, almarja al-tamm, som i så fald ville være den universelt anerkendte autoritet med den ultimativt største indsigt i religionen. Ikke desto mindre har der altid været en pluralitet af maraji. $^{13}$

Det flydende og relativt abstrakte hierarki mellem maraji etableres dog ikke blot af den gensidige anerkendelse af kunnen og antallet af mujtahid, der følger hans lektioner, men også størrelsen af deres følge af muqalideen (Alagha 2006:74-75). Der er tale om en meget uformel struktur, hvor en mujtahid selv kan erklære sit marjaiyya, men samtidig forudsætter anerkendelse både fra lægmand og kolleger. Den enkelte muqallids valg af marja, som skal ske blandt nulevende maraji, er også uformelt og foranderligt. Det gør det meget vanskelig at identificere og vurdere, hvor mange tilhængere de enkelte maraji har. Netop fordi marjaen er konstitueret som fejlbarlig, er det - i modsætning til forholdet til imamen - op til folk selv at vælge en marja, som de mener kan vejlede dem til det retledede liv, som skal sikre dem en plads i himmerige. Dette valg - eller rettere den akkumulering af valg - medfører, at selvom muqallid-positionen altså umiddelbart er artikuleret med en mindre privilegeret direkte adgang til religionens refortolkning end marja- 
positionen, er positionen samtidig konstitueret med stor indirekte indflydelse, fordi $m u$ qallideen er med til at så at sige vælge hvem, der skal have en privilegeret adgang til religionen, idet størrelsen af den enkelte marjas følge er af stor betydning.

Idet omfang at folk er tilstrækkeligt impliceret i den religiøse diskurs til at følge en marja, og dermed selv acceptere en muqallid-position, nyder marjaen stor betydning med sin meningsfiksering af dele af folks livsverden ${ }^{14}$. De dele af muqalideens livsverden, som marjaen accepteres legitim ret til at meningsudfylde, har varieret betragteligt over tid og mellem de enkelte diskurser. Traditionelt har marjaens autoritet overvejende omfattet sociale, familiemæssige og personlige livsområder med behandling af alt daglig hygiejne, ægteskabelige forhold og religiøse ritualer, men har også rakt langt ind i det politiske rum. Den religiøse nyfortolkning, som fremtrædende ulama med blandt andet Ruhollah Khomeini og Baqir al-Sadr - qua deres marja-status - i spidsen formulerede ved Najafs akademier i 1960'erne, indebar således en øget legitimitetsrækkevidde langt ind i det politiske felt, således at de maraji, der tilhørte den aktivistiske strømning, også gjorde krav på indflydelse i det politiske rum. Strømningen rummede dog forskellige fortolkninger af hvordan. Nogle vurderede, at den religiøse retledning indebar at give politisk retning og fungere som politisk drivkraft, mens andre mente, at de religiøse ledere ligefrem skulle fungere som samfundets politiske lederskab. Blandt sidstnævnte fandt man ayat'allah Khomeini, som på baggrund og i tilgift til marjaiyyat al-taqlid institutionen foretog en sammenkobling af det religiøse og det politiske lederskab. Det skete i hans teori om velayat-e faqih, eller på arabisk wilayat al-faqih, Juristens (i religiøs jura, fiqh) formynderskab/vejlederskab.

\section{Wilayat al-faqih}

Khomeinis teori om wilayat al-faqih, Juristens formynderskab, sammensmeltede det religiøse og det politiske lederskab i én person, wali al-faqih. Det var netop placeringen af politisk autoritet hos én retfærdig faqih, der udgjorde grundlaget for etableringen af en islamisk stat, hvilket ellers hidtil havde været betragtet som en umulighed uden de ufejlbarlige imamers tilstedeværelse (Alagha 2006:90). Wali al-faqih blev således institutionaliseret som rahbar moazzam, фverste leder i Den Islamiske Republik Iran med særdeles 
omfattende beføjelser, som øverste instans indenfor såvel den lovgivende, udøvende og dømmende magt (jf. Den Islamiske Republik Irans forfatning, art. 57, 110). ${ }^{15}$ Det var denne post, som Khomeini selv beklædte frem til sin død i 1989, hvorefter han blev efterfulgt af den til dato siddende Ali al-Khamenei. Qua sin position som marja al-taqlid havde Khomeini privilegeret adgang til at videreudvikle marjayyia-institutionen med en genfortolkning, der ændrede de ellers fremherskende religiøse magtstrukturer. Den politiske autoritet blev fortsat legitimeret med reference til den mytologiske Imam al-Mahdi, men i Imamens fravær skulle den politisk, økonomiske og juridiske autoritet betros til én centraliseret religiøs ledelse, der kunne sikre retledning. Dét, der ifølge Khomeini kvalificerede wali al-faqih til en så ultimativ magt, var en unik indsigt i guddommelig lov, jordiske forhold samt hans unikke egenskaber indenfor retfærdighed og fromhed, som gjorde faqih i stand til lede det retledede samfund i overensstemmelse med Guds ønske herfor (Khomeini 1970). Wali al-faqih blev altså meningsfikseret med en yderst privilegeret adgang til religionen. Adgangen adskilte sig fra marjaiyyatet på navnlig to måder. For det første blev én person tildelt en helt unik adgang til religionen i modsætning til de facto pluraliteten af maraji. Hvor muqalideen kunne vælge indenfor denne pluralitet af maraji, svandt lægmands råderum ind i forholdet til wali al-faqih, idet dennes unikke formynderskab hævdes at være gyldig for hele ummah (og dermed heller ikke kun indenfor Irans nationalgrænser). Hvor marjaiyya al-taqlid institutionen altså resulterede i en pluralitet af uformelle, sidestillede magtstrukturer af positioner, maraji, hver med privilegeret adgang til fortolkning af religionen, blev med wilayat al-faqih italesat med en unik adgang. For det andet var det felt, som privilegeringen omfattede anderledes end marjaens. Wali alfaqihs politiske autoritet blev ikke meningsfikseret som en erstatning for, men snarere et supplement til marja al-taqlid institutionen. I lidt forsimplet form kan man sige, at det traditionelle marjaiyya overvejende har bestået i vejledning af sine tilhængere i det spirituelle og private rum, mens wali al-faqihs lederskab tæller det politiske rum. Wali alfaqihs lederskab var dog funderet i dennes position som marja al-taqlid. Den nøjagtige distinktion mellem de to er dog forblevet uklar. Khomeini formåede således aldrig at afklare den præcise relation og afgrænsning mellem de to institutioner inden sin $\mathrm{d} ø \mathrm{~d}$. 


\section{Wilayat al-faqihs betydning for Hizb'allah}

Det er vanskeligt at overvurdere wilayat al-faqihs betydning for Hizb'allah. Wilayat alfaqih har ganske enkelt været hjertet og rygraden i hele Hizb'allahs ideologiske struktur lige siden organisationens dannelse. Accept af faqih's autoritet er derfor en forudsætning for adgang til organisationen, ligesom ideologien formidles i alle organisationens aktiviteter med billeder af wali al-faqih på gader og stræder til organisationens undervisningsorganer såsom hawzas, skoler og spejderkorps (Saad-Ghorayeb 2002:kap 2, Harb og Leenders 2005). Én Hizb'allah-forsker har ligefrem kaldt the party [Hizb'allah] itself [...] an extension of wilayat al-faqih (Hamzeh 2004:34). Organisationen betragter således wali al-faqih som legitim stedfortræder og formynder for den tolvte imam, imam alMahdi og derfor som en decideret hellig position (Mussawi, 2004). Den nuværende generalsekretær Hassan Nasrallah forklarede kort efter organisationens oprettelse, at He who rejects the authority of the wali al-Faqih, rejects God, Ahlul beit [ efterkommerne af Imam Ali og hans kone Fatima] and is almost a polytheist (Nasrallah, i Saad-Ghorayeb, 2002:64). Med andre ord er en afvisning af wali al-faqih i Hizb'allahs øjne grænsende til at afvise religionen selv. Ifølge Hizb’allah er det altså nødvendigt at følge de regler og systemer, som wali al-faqih opstiller, for at leve og handle i overensstemmelse med islam (Qassem 2005:70-71). En accept af religionen betyder altså også en accept af wali-faqihmagtstrukturen. Wali al-faqih bliver på den måde meningsfikseret med en unik position i forhold til formulering af religionen. Som daværende leder af Hizb'allahs tænketank, nuværende parlamentsmedlem, Ali Fayyad forklarede: It is wali al-faqih that guides everything, and it is the compas (Fayyad int., jf. Hizb'allah 1985: art. 1). ${ }^{16}$

Wali al-faqihs unikke adgang til at fortolke religionen betyder, at Hizb'allahs verdensbillede og handlemuligheder formuleres af wali al-faqih qua dennes unikke adgang til at fortolke religionen. Det er således wali al-faqih, der anerkendes ret til at rubricere verdens aktører i de aktørkategorier, som Hizb'allah opfatter og arbejder på baggrund af. Det er altså wali al-faqih, og ikke Hizb'allah selv, der i sidste ende definerer organisationens løbende definering og redefinering af venner og fjender (jf. Saad-Ghorayeb 2002:67). Der har derfor aldrig været forskel på de fjendebilleder, som wali al-faqih Ruhollah Khomeini eller senere Ali al-Khamenei, har tegnet op og de, som Hizb'allah har fulgt og handlet i forhold til. I den religiøstinformerede meningsfiksering, som Hizb'allah trækker 
på, er det den amerikanske ledelse (ikke den amerikanske befolkning) og den israelske stat, der er italesat som nutidige manifestationer som henholdsvis kilden til ondskab ${ }^{17}$ og produktet af rendyrket ondskab. ${ }^{18}$ Italesættelsen indebærer, at den amerikanske ledelse og staten Israel tillægges nogle immanente, uforanderlige motiver samt en specifik relationel position som de retlededes definitoriske modsætning i den kosmiske konflikt. Øvrige nationale og internationale aktører italesættes kontekstuelt som venner og fjender i forhold til, hvorvidt disse opretholder et fjendskab til og gør modstand mod de jordiske manifestationer af det onde, altså den amerikanske ledelse og Israel.

Ligeledes er wali al-faqih konstitueret med privilegeret adgang til at formulere rammerne for religiøs retledet handlinger, givet de konkrete omstændigheder. Faqihen lægger således rammerne for, hvordan modstanden i den kosmiske konflikt skal ske og med hvilke redskaber, eller, med andre ord, hvad der er tilladt indenfor de syv forskellige jihadmodaliteter, som Hizb'allah arbejder med. Fayyad forklarede således:

He [wali al-faqih] draws the basic principles, the basic goals and the general policies, but he does not get involved in specific details. According to Hizb'allah, the wali al-faqih draws the basic path, but the way this basic path is taken and used is according to each arena (Fayyad, int.).

Dermed menes wali al-faqih at skabe konsistens i de retlededes modstand i den kosmiske konflikt mod det onde for at skabe størst mulig effekt (Qassem 2005:70). Fayyads udtalelse peger på to væsentlige aspekter: Dels at wali al-faqih har en unik priviligering i forhold til at definere, hvad der falder indenfor den religiøse retledning, dels at hvad der er religiøst retledet betinges af de konkrete, lokale betingelser. To eksempler herpå har været brugen af martyrmissioner/selvmordsmissioner heri samt politisk deltagelse i, hvad der ellers betragtes som et illegitimt system. Det var således efter en sanktionering fra wali al-faqih Khomeini, at det blev tilladt for Hizb'allah at foretage sin første martyrmission i Zur i november 1982. Uden wali al-faqihs billigelse havde denne praksis ikke været tilladt (Saad-Ghorayeb 2002:67). Et andet eksempel var Hizb'allahs deltagelse i det første parlamentsvalg i Libanon efter borgerkrigen i 1992. Her var det den nuværende wali al-faqih Ali al-Khamenei, som traf beslutning, om at dette var tilladt (Qassem 2005:191). Betoningen af den konkrete lokale kontekst reflekteres i de to overordnede måder, som faqihen udarbejder sine vurderinger på. 
For det første udstikker wali al-faqih på eget initiativ vurderinger, som gælder generelt for hele ummah'en - i praksis dem der anerkender hans legitimitet, herunder Hizb'allah. For det andet kan han tage stilling til spørgsmål ved konkrete nationale kontekster på forespørgsel af eksempelvis aktører såsom Hizb’allah. (Qassem 2005:187-189).

Der er dog tale om udstikning af overordnede retningslinjer og ikke indblanding i detailregulering. Således hævdes Hizb'allahs lederskab, planer og implementering styret af organisationen selv. Som Nasrallah i 1993 selv formulerede det:

[...] both the supreme leader and the Imam, who wields legal authority, believe that we are an occupied country and that, as such, it is our legal right right to resist this occupation. As to how we do it, they leave the matter for us to decide whether we throw a bomb or attack a position with Katyushas, and do not interfere at all.[...] the supreme leader, who has the right to interfere, does not do so at all; he only says that there should be a resistance, and Hezbollah does the rest (Nasrallah 31.8.1993: 134 , se endvidere Hamzeh 2004: 70). ${ }^{19}$

Wali al-faqih udspænder så at sige den bane, som Hizb'allah må spille på og bestemmer hvilke redskaber som organisationen har til rådighed i værktøjskassen, men hvordan og hvornår de bliver brugt, er op til Hizb'allah selv. På den måde underlægger Hizb'allah sig fuldt ud wali al-faqihs lederskab qua dennes magtposition i religionen. Det er således i dag Khameneis beføjelse at lægge rammerne for Hizb'allahs gøren og handlen i forhold til de forskellige typer jihad samt klassificering af venner og fjender.

Hizb'allah synes dog at have opnået stadig større aktørautonomi indenfor wali al-faqihs vejledning i løbet af sine snart tre årtiers eksistens. Det mest håndfaste eksempel herpå så man i forbindelse med, at Hizb'allah for første gang valgte at gå med i den libanesiske regering i 2005. Selvom det var et markant skift i forhold til partiets tidligere praksis, faldt den religiøse legitimering ikke fra Khameneis hånd, men fra den Hizb'allah allierede libanesiske sheikh Afif al-Naboulsi i Jabal Amail (Alagha 2006:174, 192). Man kan pege på to primære årsager hertil. For det første har Hizb'allah med tiden udviklet stor egenkapacitet til at foretage religiøse vurderinger. Sammen et veludbygget apparat af præcedensskabende vurderinger fra Khomeini og Khameneis hånd, der har nuanceret grundlaget for at foretage vurderinger - har det givet bedre grundlag for at vurdere religi- 
øsiteten af egne handlinger. Dette er som sådan en bevægelse indenfor magtstrukturen, mens den anden årsag som sådan indebærer en forandring af wali al-faqih og Hizb'allahs relationelle position i strukturen og dermed den religiøse diskurs som sådan. Årsagen skal nemlig identificeres i den udfordring, som ayat'allah Khomeinis død medførte, som umuliggjorde den hidtidige sammenkobling af marjaiyya al-taqlid og wilayat al-faqih, som ellers havde været en essentiel komponent $\mathrm{i}$ den oprindelige begrundelse for sidstnævntes religiøse legitimitet.

Med ayat'allah Khomeinis død den 3. juni 1989 blev wilayat al-faqih institutionen fundamentalt udfordret. Ved hans død var der ingen maraji, der længere tilsluttede sig Khomenis version af wilayat al-faqih, som den var blevet gennemført i Iran. Få år efter Khomeinis død var ayat'allah Hosein Ali Montazeri, der ellers var udpeget af Khomeini som sin efterfølger, blevet stadig mere skeptisk over den praktiske implementering af ideologien og udtrykte blandt andet sine tanker om at begrænse faqih'ens autoritet i en 600 sider lang afhandling (Ehteshami og Zweiri 2007: 28). I mangel af bedre blev den tidligere præsident - og wilayat al-faqih-tro - Ali al-Khamenei udpeget (Roy 1994:173-174). Det var et yderst kontroversielt valg, da Khamenei før indsættelsen ikke besad de tilstrækkelige religiøse akkreditiver. Khameneis religiøse akkreditiver begrænsede sig til en status af hojjat al-islam, islams bevis, og han havde derfor ikke den nødvendige religiøse rang. Dette var ellers et krav stadfæstet i den iranske forfatning, men med henvisning til at Khameneis tjeneste for den islamiske republik talte lige så meget som avanceret religiøs træning, blev forfatningen revideret (Roy 1994:173-174, Takeyh 2009: 117). Som nævnt var selve wali al-faqih en videreudvikling af marjaiyyat al-taqlid institutionen, idet det var en unik indsigt i fiqh, den religiøse jura, i kombination med indsigt i temporale forhold, der kvalificerede en person til at varetage det politiske lederskab. Der var derfor mange - heriblandt nedenfor nævnte ayat'allah Muhammed Hussein Fadlallah -, der så det som en erodering af selve institutionens religiøse legitimitet. Ikke desto mindre anerkendte Hizb'allah med det samme Khameneis autoritet om end organisationen ikke tildeler Khamenei den samme religiøse status som Khomeini (Qassem 2005: 55). Selvom Hizb'allah derfor fortsat arbejder indenfor rammerne udstukket af Khamenei kan hans suboptimale religiøse akkreditiver have været medvirkende til at skabe større plads i Hizb'allahs udfyldelse heraf. Selvom wali al-faqih helt overordnet fortsat udstikker ram- 
merne for Hizb'allahs handlinger, har organisationen i dag således langt større frihedsgrader og ansvar for udførelsen af handlinger, end det var tilfældet tidligere.

\section{Hizb’allahs aktørstatus i forhold til marjaiyya al-taqlid}

Hizb'allah har haft et sammenfald mellem wali al-faqih og marja al-taqlid, når det har været muligt. Således betragtede Hizb'allah indledningsvist Ruhollah Khomeini og fra 1994 Ali al-Khamenei som organisationens officielle marja (eks. Nasrallah 26.5.2000, Fayyad, int.). Khomeini tildeles dog en helt særlig betydning af organisationen. Hizb'allah benævnte ham ligefrem som 'religionens fornyer' med henvisning til den shiitiske traditions betoning af, at der én gang i hvert islamisk århundrede skulle fremkomme en person, der vil bring ny liv i religionen. Med udnævnelsen af Khomeini til religionens fornyer, sidestilles han ligefrem med et par af Imamerne, der tillige i deres tid blev udpeget til denne ærestitel (Saad-Ghorayeb 2002:65). Hizb'allahs hawzat al-ilmiyya, religiøse akademier, var derfor også underlagt Khomeinis autoritet, ligesom organisationen fulgte Khomeinis vurdering af tidspunkter for religiøse højtider som ashura og ramadan (Abisaab 2008: 243, 246). Efter Khomeinis død fulgte en række turbulente år, hvor Hizb'allah pegede på forskellige maraji. Indledningsvis pegede organisationen på ayat'allah sayyed Abdul Qasim al-Khoi, men da han døde pegede Hizb'allah fra 1993, i lighed med Khamenei, på den iranske alim Muhammed Ali al-Araki, som dog døde allerede året efter (hvilket dog ikke kunne som den store overraskelse, eftersom han var 106 år, da han blev marja). I det deraf følgende magttomrum erklærede Khamenei i december 1994sit eget marjaiyya, med hjælp fra en magtfuld organisation af undervisere fra de religiøse akademier i den Qom, der udfærdigede en anbefalingsliste over syv ulama, inklusive Khamenei, som folk opfordredes til at vælge som deres marja (Chehabi 2006b:299). Den mødte (og møder) stor modstand i konservative, religiøse kredse i Iran (og udenfor landets grænser), fordi hans religiøse akkreditiver blev anset som utilstrækkelige til, at han kunne accepteres som den mest lærde i fiqh, kravet for at blive marja (Sankari 2005:264). Resultatet blev den kuriøse og nyskabende konstruktion, at Khameneis marjaiyya begrænsede sig til muslimer udenfor Iran. Argumentet var, at hans ansvar som wali al-faqih for hele den muslimske nation, ummah, nødvendiggjorde hans marjaiyyat, idet det gjorde det muligt at tilbyde shiiter udenfor Iran, som boede i et ikke-revolutionært miljø, mulighe- 
den for at vælge en marja, der videreførte den islamiske revolution. Andre kvalificerede revolutionære marajis tilstedeværelse i Iran betød, ifølge ham selv, at det ikke var påkrævet, at han også var det (Chehabi 2006b:300). På den måde forsøgte Khamenei igen at sammenbinde de to magtstrukturer, der er afledt af henholdsvis wilayat al-faqih og marjaiyya, på trods af at han selv var årsag til, at disse blev brudt. Khameneis (selv)forfremmelse til marja på trods af manglende religiøse akkreditiver fremstod samtidig i høj grad som et forsøg på at binde det vigtige marjaiyyat i den Islamiske Republik Iran som primus inter pares i den shiitiske verden, eller med Shaery-Eisenlohrs ord shiaislams Vatikan (Shaery-Eisenlohr 2008: 144). Det var en status, som Hizb'allah fra starten formelt accepterede. Som sådan anerkendte Hizb'allah altså Khamenei en privilegeret religiøs position også indenfor de sociale områder, der hører under marjaiyyatet. Dét sagt, har Hizb'allah aldrig lagt skjul på, at Khamenei ikke når Khomeinis niveau indenfor fiqh.

Khameneis marjaiyyat og Hizb'allahs tilknytning hertil sendte organisationen på kollisionskurs med Libanons mest prominente og respekterede alim, Muhammed Hussein Fadlallah. Fadlallah havde ellers været en helt afgørende figur og drivkraft i det islamiske miljø, hala al-islamyyah al-shiyyah, som Hizb'allah voksede ud af, og siden haft stor betydning for og indflydelse mange i og omkring organisationen som en fast støtte til den væbnede modstand mod Israel. ${ }^{20}$ Efter en kort flirt med wilayat al-faqih i starten af 1980'erne var Fadlallah blandt de mange kritikere af institutionens implementering (Sankari 2005: 287, Saad-Ghorayeb 2002:64, Kramer 1997: 104). Hizb'allah betragtede det derfor i høj grad også som en udfordring af Khameneis autoritet i Libanon, da Fadlallah erklærede (efter et intermezzo med Sistani som sin marja) sit eget marjaiyyat i stedet for at anerkende Khameneis. Fadlallah begrundede dette med, at arabere behøvede en leder, der talte deres sprog og forstod deres umiddelbare miljø i stedet for en iransk marja, der ikke havde indsigt $\mathrm{i}$ den arabiske libanesiske hverdag. I forlængelse heraf langede han ud efter den iranske ulama for at forsøge at etablere Iran med en særlig status indenfor shia islam. Det førte i de følgende år til kold luft mellem Fadlallah på den ene side og Khamenei, det religiøse establishment i Qom i Iran og Hizb'allah, på den anden (ShaeryEisenlohr 2008: 144). ${ }^{21}$ 
Hizb'allahs forhold til Khamenei, Fadlallah og de herres respektive marjaiyyat er dog mere kompliceret end som så. For det første har Hizb'allah opnået større egenautonomi indenfor sin relation til Khameneis marjaiyyat. Den 17. maj 1995 blev generalsekretær Hassan Nasrallah og Muhammad Yazbak, leder af Hizb'allahs juridiske dimension, udnævnt til Khameneis religiøse repræsentanter, wakilayn shariyyan, i Libanon (Alagha 2006: 45). Derved blev de bemyndiget til blandt andet til at modtage den religiøse afgift khums og andre religiøse donationer fra muqalideen på vegne af marja al-taqlid Khamenei. I denne sammenhæng er det dog vigtigere, at udpegelsen af Nasrallah og Yazbeck som wakilayn også betød, at disse blev bemyndiget til i nogen grad og indenfor visse sociale områder selv at fortolke udførelsen af religiøse pligter i en libanesisk kontekst i Khameneis navn (Alagha 2006: 192). Hizb'allah blev således et 'filter' for Khameneis overordnede religiøse vurderinger indenfor de private, familiemæssige og rituelle sfærer skulle igennem, før de nåede ud i de libanesiske gader og hjem. Dette giver Hizb'allah et øget aktørråderum. Selvom Hizb'allah altså anerkender Khameneis religiøse autoritet som marja al-taqlid, har den libanesiske organisation altså i praksis opnået selvstændighed i implementeringen indenfor dette område - i lighed med hvad man så i forhold til wali al-faqih positionen.

For det andet synes Hizb'allahs forøgede frihedsgrader i forhold til Khamenis wilayat og marjaiyyat udfyldt med et $\emptyset$ re til en anden religiøs autoritet, nemlig marja al-taqlid $\mathrm{Mu}$ hammed Hussein Fadlallah. Mens Fadlallahs forhold til Iran i femten år forblev så betændt, at alimen først omkring nytår 2009 igen mødtes med iranske repræsentanter, var forholdet til Hizb'allah mere foranderligt. Forholdet mellem Hizb'allah og Fadlallah tøede i først omgang op, da sidstnævnte lovpriste den islamiske modstands bedrifter efter Israels tilbagetrækning i 2000 og forsvarede Hizb'allahs ret til at bevare sine våben (Sankari 2005:268). Alligevel oplevede man blandt andet en fyring af en højtstående person i Hizb'allahs store organisation - chefen for organisationens tv-station al-Manar - med henvisning til, at han var loyal mod Fadlallah (Norton 2007:118). Ligeledes var Fadlallah og Hizb'allah på kant i forholdet til Hizb'allahs ageren i det libanesiske politiske system, hvor ayat'allahen flere gange kritiserede, at organisationen kaldte politisk deltagelse en religiøs pligt, taklif, hvilket han mente var at bruge det religiøse begreb som 'salgsvare i en politisk basar'(Alagha 2006: 62). På den anden side har organisationen aldrig stillet 
spørgsmålstegn ved Fadlallahs religiøse autoritet, men tværtimod et utal af gange rost hans religiøse meritter (se eks. Nasrallah 31.8.1993: 137, Moussawi, int.). Højtstående ledere i Hizb'allah har således kontinuerligt frekventeret Fadlallahs prædikener, ligesom det er velkendt, at vice-generalsekretær Naim Qassim jævnligt besøgte Fadlallah for konsultationer (Sankari 2005:268). Det har sat sig spor. Navnlig på tre områder synes Fadlallahs reformistiske gradualisme og pragmatisk aktivisme at have været en stor inspirationskilde for Hizb'allah. Således menes Fadlallah indenfor det politiske område dels at have haft stor indflydelse på den fløj i Hizb'allah, der gik ind for deltagelse i det libanesiske politiske system fra 1992, dels at have fungeret som retningspil for den infitahstrategi, åbenheds-strategi i forhold til samarbejde med andre konfessionelle grupper, som organisationen har fulgt siden 1991 (Azani 2009:98, Sankari 2005:246). Derudover virker Fadlallah til at have inspireret et skift i organisationens fors $\emptyset \mathrm{g}$ på at udbrede den islamiske bevidsthed. Fra at Hizb'allah i de første år arbejdede med at frembringe en islamisk atmosfære oppefra ved hjælp af ydre tvang, hvor eksempelvis tøjregler blev håndhævet med korporlige midler og hvor butikker, der solgte alkohol kunne risikere at få smadret hele lageret, foregår udbredelsen i dag langt mere diffust, med en spredning nedefra gennem organisationens sociale apparat og medier, i lighed med den praksis, som Fadlallah altid har promoveret. ${ }^{22}$ Mens et Hizb'allah med forøgede frihedsgrader indenfor Khameneis marjaiyyat og wilayat navnlig i det seneste årti i praksis har været præget af Fadlallahs marjaiyyat, har grænsen dog gået ved udfordringer af hjørnestenen i Hizb'allahs religiøse univers, wali al-faqihs unikke autoritet. Fadlallahs udråbelse af eget marjaiyyat, og den dermed implicitte udfordring af Khameneis ditto, udfordrede wali alfaqihs autoritet, dels fordi den implicit satte spørgsmålstegn ved Khameneis religiøse legitimitet, dels fordi det kunne tolkes som en kritik af Hizb'allahs accept af iransk politisk styring qua wilayat al-faqih-institutionen.

Der er dog endnu et væsentligt aspekt af Hizb'allahs relation til marjaiyyatet. Om end Hizb'allah stærkt opfordrer sine medlemmer og tilhængere til at følge organisationens eksempel og acceptere Khomeini og senere Khamenei som marja, fritstilles medlemmer og tilhængere i deres personlige valg af marja (Saad-Ghorayeb 2002:65). Ganske få menes at have fuldt disse opfordringer. I stedet følger overvejende arabiske maraji. Hizb'allahs accept af Khomeinis marjayyiat-adskillelse sig således fra et flertal af libane- 
siske shiiter (i den udstrækning, at de libanesiske shiiter på dette tidspunkt overhovedet fulgte en marja), som fulgte den Najafbaserede Abu al-Qasim al-Kho'i, der siden 1970 var blevet betragtet som marja at-taqlid (Walbridge 1997:63-87). Selvom Hizb'allah opbakning blandt den shiitiske befolkning er vokset massivt $\mathrm{i}$ årene, der er passeret siden Khomeinis død, synes det ikke at have medført et stort libanesisk følge til Khameneis marjaiyya. Der findes dog ingen præcise opgørelser på området, idet forholdet mellem muqallid og marja er uformelt, omskifteligt og vanskeligt målbart. Forskere på området er dog samstemmende enige i deres vurdering af, at et stort flertal af Libanons shiiter, heriblandt Hizb'allahs støtter og medlemmer, i stedet har fulgt enten ayat'allah Ali alSistani i Irak eller den libanesiske ayat'allah Fadlallah. Enkelte menes dog fortsat at følge Khomeini eller Khoi posthumt, selvom dette bevæger sig i gråzonen af det tilladelige. (Deeb 2006:71, 94) ${ }^{23}$. Det betyder, at hverdagslivet i privaten hos de fleste libanesiske shiiter i højere grad er påvirket af Sistani og Fadlallah end af Khamenei. Når den almindelige libanesiske shiit - herunder Hizb’allahs støtter og tilhængere - søger mod sin marja i forhold til hvordan familiære og rituelle aspekter af det sociale liv skal indrettes til at leve i overensstemmelse med Guds ord, vender de sig altså i højere grad mod Sistani og indtil for nylig Fadlallah end Khamenei. ${ }^{24}$ Det bemærkelsesvise herved er, at såvel Ali alSistani som Muhammed Hussein Fadlallah afviser Hizb'allahs wilayat al-faqih i den nuværende implementerede udgave, som Khamenei og Hizb'allah bakker fuldstændig op om (Sankari 2005: 287, Saad-Ghorayeb 2002:64, Kramer 1997: 104, Sistanis hjemmeside, sistani.org). På den måde kan man groft sagt konkludere, at Hizb’allahs politiske rammer udstikkes af wali al-faqih Ali al-Khamenei, mens de menige shiiters hverdag fra Hizb'allahs side i praksis er blevet overladt til Sistani og Fadlallah.

Hizb'allahs position indenfor de religiøse magtstrukturer, der resulterer af marjaiayyat al-taqlid institutionen, er altså ganske kompleks. Selvom Hizb'allah anerkender Khameneis marjaiyyat, er det en tilknytning, der kvalificeres på tre måder. For det første overlades organisationens medlemmer og støtter selv at vælge, hvilket betyder, at størstedelen i stedet har fulgt maraji Sistani og Fadlallah i deres dagligdag. For det andet har Hizb'allah som organisation opnået forøgede frihedsgrader i forhold til Khameneis marjaiyyat som organisation. For det tredje har Hizb'allah fundet stor inspiration hos Fadlallah i udfyl- 
delsen heraf. Grænsen har dog været, når denne udfordrede den vitale magtstruktur, som følger af wilayat al-faqih, i Hizb'allahs religiøse ideologi.

\section{Khamenei optegner banen, men Fadlallah og Sistani bestemmer hverdagen}

En opmærksomhed på de religiøse magtstrukturer, der er indlejret i Hizb'allahs religiøse diskurs, kan bidrage med en væsentlig nuancering af, hvorfor Hizb'allah handler som de gør, og hvordan de påvirkes af eksterne aktører. Religiøse magtstrukturer influerer således signifikant på Hizb'allah som en organisation, der forstår og fremstiller sig selv i og på baggrund af en altomfattende religiøs ideologi, har religiøse autoriteter privilegeret adgang til at forme både organisationens grundlæggende verdensbillede samt rammerne for religiøs retledning indenfor distinkte sociale felter. Organisationens position indenfor disse strukturer har dog udviklet sig signifikant gennem tiden, så den i dag handler med større autonomt aktørråderum indenfor de religiøse magtstrukturer end tidligere. Hjørnestenen i Hizb'allahs ideologi har siden organisationens etablering været wilayat al-faqih, som har placeret det religiøse lederskab indenfor det politiske felt hos én autoritet, tidligere Ruhollah Khomeini, efterfulgt af Ali al-Khamenei. Det betyder, at organisationen følger de overordnede rammer for handlinger og kategorisering af venner og fjender, som wali al-faqih meningsfikserer i og på baggrund af den religiøse diskurs. Organisationens frihedsgrader til autonomt at udfylde (og i nogen grad forme) rammerne er dog i dag omfattende. I udfyldelsen af dette råderum har marja al-taqlid Muhammed Hussein Fadlallah frem til sin død i 2010 nydt stor indflydelse, på trods af Hizb'allahs formelle accept af Khameneis marjaiyyat. Samtidig menes et flertal af Hizb'allahs individuelle medlemmer og støtter at følge Ali al-Sistani og indtil hans død, Fadlallah. Det betyder, at mange libanesiske shiiters hverdag i højere grad præges af arabiske maraji end Khamenei. Groft sat op betyder det altså, at det er Khamenei, der tegner banen udadtil, mens det er Sistani og Fadlallah, der i praksis optegner hjemmebanen - i hvert fald så længe, at de ikke truer Khameneis politiske autoritet. 
Rune Friberg Lyme er cand.scient.pol. og har forsket i Hizbollah og libanesiske forhold ved Dansk Institut for Internationale Studier samt fungeret som rådgiver for Udenrigsministeriet.

\section{Primære kilder}

Hizb' allah, 1985: "Open letter adressed by Hizbullah to the oppressed in Lebanon and the world", in Alagha, Joseph, 2006: The Shifts in Hizbullah's ideology: Religious Ideology, Political Ideology, and Political Program, Amsterdam University Press Interview med Ali Fayyad, Director of the Consultative Center For Studies \& Documentation og medlem af Majlis al-Siyassi, foretaget den 27. juni 2004, Haret Hreik, Beirut

Interview med Nawaf al-Mussawi, Chargé de Relationes Internationales, foretaget 27. juni 2004, Haret Hreik, Beirut

Nasrallah, Hassan, taler og interviews. Hvis ikke andet er angivet er disse fundet på www.hizbollah.org, som idag er ude af drift

31.8.1993: "Who is Sayyed Hassan Nasrallah?”, in Noe, Nicholas, 2007: Voice of Hezbollah - The statements of Sayyed Hassan Nasrallah: 143, Verso

24.4.2000: Text of the Interview arranged by "al Jazeera" Satellite Channel with the Secretary General of Hizbullah his Eminence Sayyed Hassan Nasrallah

19.3.2002: Interview with the Al Watan Newspaper

24.3.2002: The Secretary-General of Hizbullah "Sayyed Hassan Nasrallah" addresses the people at the conclusion of their march on the 10th day of Muharram

23.5.2002: The Secretary General of Hizbullah "Sayyed Hassan Nasrallah" addressing the people at the great festival celebrated by Hizbullah prior to the national day for the resistance and liberation, and the anniversary of the Birthday of the Honorable Prophet Muhammad (P)

4.6.2002: Address of his eminence the secretary general of Hizbullah Sayyed Hassan

Nasrallah on the 13th commemoration of his holiness Imam al Khomeini

8.11.2003: Word of the Secretary-General of Hizbullah, his eminence, Sayyed Hassan Nasrallah on the Ritual Iftar of the Women's Association in Hizbullah 
17.11.2003: Word of the Secretary-General of Hizbullah, his eminence, Sayyed Hassan

Nasrallah on the night preceding 23rd of the blessed month of Ramadan 1424

20.2.2004: Word of the Secretary-General of Hizbullah, his eminence, Sayyed Hassan

Nasrallah, on the First Night of the Sacred Month of Muharram 1425 A.H.

2.3.2004: Word of the Secretary-General of Hizbullah, his eminence, Sayyed Hassan

Nasrallah on Day 10 of Muharram year 61 A.H.

27.3.2004: Word of the Secretary-General of Hizbullah, his Eminence, Sayyed Hassan

Nasrallah In memory of Martyr Sheikh Ahmad Yassin

18.5.2004: Word of the Secretary-General of Hizbullah, His Eminence, Sayyed Hassan

Nasrallah, At the Festive Assembly, in Support of the Wronged Iraqi People

23.2.2006: Hizbullah Sec.-Gen. Hassan Nasrallah- the Destruction of the Samarra

Mosque is a zionist Plot in Preparation for the Destruction of the Al-Aqsa Mosque

\section{Sekundær litteratur}

Abisaab, Rula Jurdi, 2006: "The Cleric as Organic Intellectual: Revolutionary Shi' ism in the Lebanese Hawzas", in: Chehabi (ed.): Distant relations - Iran and Lebanon in the last 500 years: 231-258, I.B.Tauris

Alagha, Joseph, 2006: The Shifts in Hizbullah's ideology: Religious Ideology, Political Ideology, and Political Program, Amsterdam University Press

Almond, Gabriel A., Sivan, Emmanuel og Appleby, R. Scott, 1995: "Fundamentalism: Genus and Species”, in: Martin E. Marty og R. Scott Appleby (Eds.)

Fundamentalisms Comprehended: Chap. 16. vol. 5, University of Chicago Press

Azani, Eitan, 2009: Hezbollah: The Story of the Party of God - From Revolution to Institutionalization, Palgrave Macmillan

Carrette, Jeremy R. (ed.), 2000: Foucault and religion: spiritual corporality and political spirituality, Routledge

- 1999: Religion and Culture by Michel Foucault, Routledge

Chehabi, H.E, 2006: "Iran and Lebanon in the Revolutionary Decade", in: Chehabi (ed.): Distant relations - Iran and Lebanon in the last 500 years: 201-230, I.B.Tauris

- 2006b. "Iran and Lebanon after Khomeini”, in Chehabi (ed.): Distant relations - Iran and Lebanon in the last 500 years: 287-308, I.B.Tauris 
Deeb, Lara, 2006: An Enchanted Modern - Gender and Public Piety in Shi'i Lebanon, Princeton University Press

Dreyfus, Hubert L. og Rabinow, Paul, 1983: Michel Foucault: Beyond Structuralim and Hermeneutics, 2. ed., The University of Chicago Press

Ehteshami, Anoushiravan og Zweiri, Mahjoob, 2007: Iran and the rise of its neoconservatives: the politics of Teheran, I.B.Tauris

Fairclough, Norman, 1995: Critical discourse analysis: the critical study of language, Longman Group Limited

- 1992: Discourse and Social Change, Polity Press

Foucault, Michel, 1980a: "Truth and Power", in Gordon, Colin (ed.): Power/Knowledge Selected Interviews and Other Writings 1972-1977: 109-133, Harvester Press

- 1980b: "Power and Strategies", in Gordon, Colin (ed.): Power/Knowledge Selected Interviews and Other Writings 1972-1977: 134-145, Harvester Press

- 1980c: "The Confessions of the Flesh", in Gordon, Colin (ed.) Power/Knowledge Selected Interviews and Other Writings 1972-1977: 194-229, Harvester Press

Hamzeh, Ahmad Nizar, 2004: In the Path of Hizbullah, Syracuse University Press

Harb, Mona \& Leenders, Reinoud, 2005: Know thy enemy: Hizbullah, ‘terrorism' and the politics of perception, Third World Quarterly, Vol. 26, no.1: 173-197

Heather, Noel, 2000: Religious Language and Critical Discourse Analysis - Ideology and Identity in Christian Discourse Today, Bern: Peter Lang

International Crisis Group (ICG), 2005: Understanding Islamism, Middle East / North Africa Report No.37 - 2 March

Jaber, Hala, 1997: Hezbollah - Born with a Vengeance, Columbia University Press

Khashan, Hilal og Mousawi, Ibrahim, 2007: "Hizbullah's Jihad Concept”, in: Journal of Religion \& Society, vol. 9

Khomeini, Ruhollah al-Musavi, 1970: Islamic Governance: Governance of the Jurist, oversat af Algar, Hamid, The Institute for Compilation and Publication of Imam Khomeini's Works, se eks. http://www.al-islam.org/islamicgovernment/

Kramer, Martin, 1997: "The Oracle of Hizballah: Seyyid Muhammad Husayn Fadlallah", in: Appleby, R. Scott (ed.) Spokesmen for the Despised: Fundamentalist Leaders in the Middle East: 83-181, University of Chicago Press 
Laclau, Ernesto og Mouffe, Chantal, 2001: Hegemony and Socialist Strategy: Towards a Radical Democratic Politics, 2.nd ed., Verso

Mervin, Sabrina, 2008: “Le Lien Iranien”, in: Mervin, Sabrina (ed.): Le Hezbollah - état des lieux: 75-89, Sindbad

Minoui, Delphine, 2008: “Les revelations d'un cofondateur Iranien du Hezbollah”, in: Mervin, Sabrina (ed.): Le Hezbollah - état des lieux: 89-93, Sindbad

Noe, Nicholas, 2007: Voice of Hezbollah - The statements of Sayyed Hassan Nasrallah, Verso

Norton, Augustus Richard, 2007: Hezbollah: a short history, Princeton University Press

NowLebanon, 2008: What lies beneath - Are the earthquakjes acts of God or acts of man?, tilgængelig på http://nowlebanon.com/NewsArchiveDetails.aspx?ID=50323

Qassem, Naim, 2005: Hizbullah: The Story from Within, Saqi Books

Piscatori, James, 2000: Islam, Islamists, and the Electoral Principle in the Middle East, Leiden ISIM

Ranstorp, Magnus, 1997: Hizb'allah in Lebanon: The Politics of the Western Hostage Crises. Macmillan Press Ltd.

Roy, Olivier, 1994: The Failure of Political Islam, Harvard University Press Saad-Ghorayeb, Amal, 2002: Hizbu'llah - Politics and Religion, Pluto Press Sankari, Jamal, 2005: Fadlallah - The Making of a Radical Shi'ite Leader, Saqi Books Shaery-Eisenlohr, Roschanack, 2008: Transnational Religion and the Making of National Identities, Columbia University Press

Rosiny, Stephan, 2007: "The Twelver Shia Online: Challenges for its Religious Authorities", in: Monsutti, Alessandro, Naef, Silvia and Sabahi, Farian (eds.): The Other Shiites - From the Mediterranean to Central Asia: 245-262, Peter Lang

Takeyh, Ray, 2009: Guardians of the revolution: Iran and the world in the age of the Ayatollahs, Oxford University Press

Torfing, Jacob, 1999: New Theories of Discourse. Laclau, Mouffe and Zizek, Basil Blackwell

Walbridge, Linda (ed.), 2001: The Most Learned of the Shi'a - The Institution of Marja' Taqlid, Oxford University Press 


\begin{abstract}
${ }^{1}$ Denne tekst vil terminologisk ligestille benævnelserne diskursteori og diskursanalyse som en forkortelse for en diskursteoretisk analytik (jf. Torfing 1999:12). Dette indikerer en midterposition i diskussionen om diskursanalysen skal ses som en metodologi eller som en teori. Michel Foucault selv opfattede sit arbejde som værende en magtanalyse, ikke en magtteori (Foucault 1980c:199), og Dreyfus \& Rabinow hævder da også at både arkæologien og genealogien i bund og grund er metodologier (1983[1982]:Introduction). Til støtte for denne position kan anføres, at der ganske rigtigt ikke er tale om en teori som hævder specifikke kausalrelationer eller søger at producere empirisk deducerbare hypoteser. Men samtidig er det problematisk at reducere tilgangen til instrumentel metode, som repræsenterer et givent felt fra et punkt udenfor (Torfing 1999:12). I stedet indgår det teoretiske og analytiske aspekt i en gensidig udviklende relation (jf. Fairclough 1999:16)

${ }^{2}$ Fairclough selv kollapser ved senere lejlighed de to sidstnævnte kategorier i en såkaldt interpersonel funktion (Fairclough 1995:14)

${ }^{3}$ Hvor Fairclough med sine dominansrelationer fokuserer på de sociale dominansrelationer, der er indlejret i diskurserne - eller i hans retorisk, ideologierne - hævdes i dette perspektiv at disse strukturer involverer differentieret adgang til at foretage fortolkninger og italesætte begivenheder og derved reartikulere den diskursive viden. Med afsæt i Foucaults viden/magt nexus, vil disse strukturer i det følgende blive benæunt magtstrukturer.

${ }^{4}$ Det mest prominente - og et af de meget få kendte - eksempel på intern splittelse i forhold til religiøs legitimitet har været i spørgsmålet om organisationens deltagelse i det libanesiske politiske system. Hizb'allahs første generalsekretær, den radikale Subhi al-Tufeili fastholdte fra midten af 1991 et ønske om en islamisk republik i Libanon og gik dermed imod wali al-faqihs religiøse vurdering - og den nye generalsekretær Abbas al-Mussawi. Tufeili forblev i første omgang en del af organisationen majlis al-shura efter, at han mistede generalsekretærposten. Det var dog en stakket frist. I maj 1997 annoncerede han en ny bevægelse, den såkaldte " De sultnes revolution”, og kaldte på civil ulydighed. Den 24. januar 1998 kom reaktionen, da Tufeili officielt blev smidt ud af Hizb'allah. Få dage efter svarede han igen ved sammen med et par hundrede væbnede mænd at besætte et af Hizb'allahs religiøse seminarer, hvilket førte til et blodigt sammenstød med den libanesiske hær (Qassem 2005: 124-125, Alagha 2006: 48)

${ }^{5}$ I marts 2002 forklarede Hizb'allahs generalsekretær oprindelsen af dette kosmiske fjendskab: Da Gud i tidernes morgen har skabt mennesket, befales alle englene at knæle for mennesket. Drevet af sin arrogance og misundelse, nægter Satan, der er jinni, en dæmon skabt af ild, som Gud har tilladt at være sammen med englene, at falde på knæ for Guds nye skabning. Det får Gud til at forbande Satan og fratage ham sin nåde. Satan udelukkes dermed fra en plads i Paradis ved Dommedag og må i stedet tilbringe Evigheden i Helvede. Satan erklærer derfor sit evige fjendskab til mennesket og sværger, at han vil gøre, hvad han kan for at skade Guds yndling, mennesket, ved at lokke det væk fra den vej, som Gud har udstukket for mennesket. Derved skabes konflikten mellem Satan og mennesket med et fundamentalt fjendskab mellem Satan og de mennesker, der følger ham, hizb'Shaytan, på den ene side og på den anden de mennesker, der handler i overensstemmelse med Guds bud og modgår Satans og hans støtter, Guds parti eller gruppe, hizb'allah (Nasrallah, 19.3.2002). Den kosmiske konflikt står altså ikke mellem Satan og Gud, men mellem mennesket og Satan. Det skyldes, at Gud i sin almægtighed er hævet over konflikten, idet universet er under Hans ultimative autoritet.

${ }^{6}$ Hizb'allahs vice-generalsekretær Naim Qassem stiller regnestykket enkelt op: Der er to frugter af jihadhandlingen: Martyrium og sejr. Martyren opnår martyriet, mens ummah og dets frihedskampere opnår sejren (Qassem 2005: 44).

${ }^{7}$ De fire aktørkategorier udledes af to delvist overlappende begrebsdikotomier: Hizb'shaytan og hizb'allah samt undertrykkere, mostakbarin, og undertrykte, mostaz'afin, som blev ayat'allah Ruhollah Khomenei formulerede. En del forskere har fejlagtigt fortolket dikotomien som en parafrasering af dar al-harb, krigens hus, og dar al-Islam, Islams hus i betydningen fredens hus, som ikke desto mindre er et specifikt sunni begreb, der ikke genfindes i den shi' itiske tradition, som Hizb'allah bygger sin ideologi på De to dikotomisæt er i stedet delvist overlappende. Mostakbarin, undertrykkerne, er sammenfaldende med hizb'shaytan, og består altså af Satan og de støtter, som Satan har formået at lokke over på sin side. Omvendt adskiller hizb'allah og mostaz'afin sig lidt fra hinanden. Hvor hizb'allah betegner den gruppe af mennesker, som lever efter Guds ord og aktivt modgår hizb'shaytan, tæller gruppen af mostaz'afin, de undertrykte, såvel de retledede, der aktivt bekæmper hizb'shaytan, og de mennesker, der ligger under og er offer for hizb'shaytans aggressive overmagt, men (endnu) ikke har valgt aktivt at modgå hizb'shaytan, som de ellers
\end{abstract}


burde. De støtter altså ikke Satan og er derfor ikke på 'det onde hold', men modarbejder ham heller ikke, som de bør, hvilket koster dem pladsen på 'førsteholdet', hizb'allah.

${ }^{8}$ Mere specifik artikuleres Shaytan, og dermed også de jordiske magter, der meningsfikseres på den baggrund, med to overordnede karaktertræk. For det første er han af natur uforanderligt ond, hvilket giver sig udslag i herskertrang, racisme, misundelse samt arrogance - netop misundelsen og arrogancen ved menneskets skabelse og særstatus foranledigede ham til at afvise Guds skaberværk. For det andet er Satan bedragerisk, snydende og misledende og forsøger med alle forhåndenværende korrumperende midler at udbrede samme ondskabsfulde arrogance, racisme og misundelse, som han selv står for (Nasrallah 19.3.2002). Hvor den første type karaktertræk består i en indbygget ondskab, er den anden type så at sige et medium for den første type, altså en måde som Satan forsøger at udbrede sin ondskab på.

${ }^{9}$ Dette skyldes en fundamental italesættelse i 'menneskekategorien', som Hassan Nasrallah har forklaret: Mennesket har en fri vilje til at valge alt, hvad der vedrører sit personlige livs detaljer såsom mad, drikke, bekladning, tale og selv private spфrgsmål. Man kan blive en fjende eller en ven". Han fortsatte med at forklare, hvad der var afgørende i kategoriseringen af venner og fjender:”[...]konflikt med den israelske fjende og modgåelse af den zionistiske fjende er de primare regler, der bestemmer vores relationer, venskaber, fjendskaber etc." (Nasrallah 19.3.2002). Italesættelsen i menneskepositionen gælder således også blandt andre Danmark og de øvrige europæiske lande, som ikke er uforanderligt onde, men 'blot' har ladet sig forblænde af Shaytans fristelser, men når handlingen ændrer, ændres også fjendeforholdet. Foranderligheden er kommet særlig til udtryk i Hizb'allahs forhold til Frankrig. Frankrig var det første land, der i august 1982 indsatte landtropper som en del af en multinational styrke i Libanon. Styrken blev dog hurtigt involveret i de interne kampe og derfor set som part i borgerkrigen. Det resulterede i et selvmords/martyrangreb på de franske faldskærmstropper i oktober 1983, som kostede 58 mennesker livet. Franskmændene slog igen med angreb på de islamiske akademier og træningslejre i Beqaa, hvor den shiitiske islamiske vækkelse blomstrede. I dag har situationen ændret sig. Hizb'allah har flere gange støttet fransk involvering i Libanon, blandt andet i form af den franske deltagelse i komiteen til implementering af den første nedfældede våbenhvile, den såkaldte April-aftale fra 1996. Som Hizb'allahs vicegeneralsekretær Naim Qassim senere har forklaret: Franskmandene blev betragtet som vores fjender, fordi de angreb vores baser i Beqaa. Frankrigs position i forhold til os har andret sig, så vi har også andret vores (Citeret i Alagha 2006:53).

${ }^{10}$ Som Hizb'allahs vice-generalsekretær, Naim Qassem, forklarer det således: Det [jihad] er en integral del af ens sande overbevisning, uden hvilken Guds accept af denne overbevisning ikke er accepteret. og fortsætter: De, der ikke lever $i$ jihad lever i personlig ydmygelse og har underlagt sig fjenden, altså Satan (Qassem 2005: 34).

${ }^{11}$ Overordnet skelnes mellem den store jihad, al-jihad al-akhbar, og den lille, al-jihad al-asghar (Qassim, 2005:34). Den lille jihad kan, igen, opdeles i to: En offensiv og en defensiv. Den lille, offensiv jihad, ibti$d a$ ' $i$, består i at udbrede Guds budskab og dermed retledningen i form af Islam over hele kloden. Den lille, defensive jihad, difa'i jihad er påkrævet, når al-ummah, den muslimske nation, rent konkret og i manifest form trues udefra af undertrykkelse, besættelse eller ydmygelse (Qassem 2005:36). den lille, defensive jihad består af mere end blot udførelsen af den væbnede handling i sig selv. Hizb'allah mener, at der religi$\emptyset$ st kan udledes tre underformer af den lille, defensive jihad, udover den væbnede handling: En forebyggende jihad, en logistisk jihad og en forhandlingsjihad,

Den store jihad adskiller sig markant fra den lille jihad, idet den ikke består i bekæmpelsen af ydre fjender, men de indre. Den store jihad gør det enkelte individ og hele samfundet klar til at deltage i den lille jihad og dermed også i den væbnede kamp. Den store jihad har i Hizb'allahs perspektiv både et individuelt og et kollektivt niveau. Hizb'allahs store, kollektive jihad består af to elementer: Den samfundsmæssige jihad og den politiske jihad. (Khashan og Mousawi 2007:13)

Det er værd at bemærke at en offensiv jihad, følge Hizb'allah og den shiitiske tradition generelt, ikke er tilladt før Dommedag. Kun de ufejlbarlige, altså Profeten Muhammed og de tolv Imamer, som har fuldstændig indsigt i Guds ønske og derfor kan bryde påbuddet om den tvangsfri religion, har nemlig ret til at erklære offensiv jihad (Alagha 2006:87). Indtil da skal den kosmiske konflikt

${ }^{12}$ Som Nasrallah i 2004 forklarede: [...] Vores kamp forudsatter legitimitet, så vores dфd bliver til martyrium. Vi må sikre, at detaljerne i kamphandlingerne harmoniseres til Guds tilladelse og tilfredsstillelse og at vores handlinger bringer os tattere på Gud (Nasrallah 20.2.2004). For et diskursendogent subjekt vil en overtrædelse af de i diskursen altså kunne true det ligeledes diskursivt definerede mål, ambitionen om paradis til fordel for en evighed i det helvede qua den religiøse kosmologiske viden indlejret i diskursen. Som 
Nasrallah forklarede om en ung dreng med martyraspirationer: Hvis vi fortceller ham, at dette er haram, at dette er selvmord og en synd, så vil denne unge mand ikke bevage et skridt fremad og ingen kan tvinge ham til at tage et skridt fremad.(Nasrallah 25.3.2002).

${ }^{13}$ Til tider hævdes den iranske og Qom-baserede ayat'allah seyyed Hossein Burujerdi at have været almarja al-azam mellem $1946 \mathrm{og}$ frem til sin død i 1961. I praksis fulgte mange arabere dog den irakiske og Najaf baserede ayat'allah Muhsin al-Hakim (Walbridge, 2001: 5). Ligeledes var Khomeini selv ikke på højden af sin popularitet den eneste marja. Faktisk menes han overgået i antal af tilhængere af den højtestimerede storayat'allah Abu'l Qasim Khoi, der var en stærk modstander af sammenblandingen af temporal politik og religion, som Khomeini var en af de største eksponenter for (Walbridge 2001: 5, se også Shaery-Eisenlohr 2008: 97-98).

${ }^{14}$ I Libanon er det først indenfor de seneste årtiers religiøse vækkelse, at større dele af den shiitiske befolkning reelt er begyndt at følge en marja. Samtidig har der været tale om store geografiske forskelle, som betød, at man helt op i 1980'erne kunne møde shiiter i den stammedominerede Beqaadal, der ikke var bekendt med marjaiyya-institutionen, mens det var langt mere almindeligt i det sydlige Libanon, der generelt havde en større religiøs bevidsthed (Walbridge 2001:6). I dag er den dog vidt udbredt i Libanon og er med til fundamentalt at strukturere relationen mellem Hizb'allah og Iran.

${ }^{15}$ Af den iranske forfatnings artikel fem kan man således læse, at [u]nder okkultationen af wali al-amr [tidens herre, Imam al-Mahdi] pålagges formynderskab [wilayah] og lederskabet af ummah [den muslimske nation] den retfardige ['adil] og fromme [muttaqi] jurist [faqih], som er fuldstandig bevidst om forholdene i sin samtid, modig, ressourcestark og med administrative egenskaber. Som en kuriositet kan det nævnes, at Michel Foudcault faktisk selv overså hierarkierne indenfor den shiitiske ulama da han som journalist rapporterede fra den islamiske revolution i Iran .

${ }^{16}$ Autoriteten, som Hizb'allah tilskrev og tilskriver faqih, rodfæstes altså ikke i hans position som den $\emptyset$ verste leder for den Islamiske Republik Iran, men alene i hans position i den religiøse ideologi. Som Nasrallah i 1993 forklarede: Forholdet med den фverste religiфse leder er uhyre vigtig for vores islamiske bevagelse, uanset om han er i Najaf eller Neauphles-le-Chateau [hvor Khomeini var i eksil 1978-1979] eller om han er leder over et helt land [...] Forholdet er derfor ikke underlagt geografi eller nationalitet: Det er et spфrgsmål om religiøs kompetence og legalitet, uanset hvor det er placeret (Nasrallah 31.8.1993: 133, jf. Qassem 2005:57).

${ }^{17}$ Dette kommer blandt andet til udtryk i det klassiske Amerika, Amerika, du er den store Satan (eks. Nasrallah 23.2.2006) eller udtalelser som moderen til al ondskab og korruption, den store Satan (Nasrallah 4.6.2002). Denne satanisering betyder, som Hizb'allahs generalsekretær Nasrallah hævder, at alle vores problemer og vanskeligheder kommer fra USA og dets politik. Det er amerikansk hegemoni, spil og tilskyndelse til vold (Nasrallah 2.3.2004), hvilket var en gentagelse af Hizb'allahs oprindelige manifest fra 1985 hvoraf fremgår Den primaere rod til dårligdom er Amerika (Hizb'allah:1985). Hizb'allah mener således, at USA - qua sin sataniske natur - i bund og grund alene bestræber sig på at dominere verden $\emptyset$ konomisk, politisk og kulturelt (eks. Mussawi int, Nasrallah 18.5.2004). Idet al dårligdom i det religiøstinformerede verdensbilllede kun kan komme fra shaytan, som den amerikanske ledelse altså fremstår som en nutidig materialisering af, må skadelige naturfænomener også oprinde herfra. Da en række jordskælv gennemrystede levanten med epicentrum i det nordlige Israel fra februar til juni 2008, erklærede Hizb'allah således også, at det var USA's værk (NowLebanon, 9.7.2008).

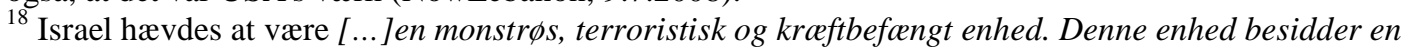
aggressiv natur, der g $\phi r$ den forbryderisk (Nasrallah 27.3.2004). Idet staten Israel ses som et rendyrket produkt af den sataniske, zionistiske ideologi, rummer og kondenserer den al Satans ondskab i en uforanderlig trang til at slavebinde, korruptere og hegemonisere sine naboer. Det får generalsekretær Hassan Nasrallah til at konkludere, at [d]et zionistiske projekt $i$ vores region i dag udg $\phi r$ spidsen af ondskab, tyranni, terror og korruption (Nasrallah 24.3.2002).

${ }^{19}$ I forhold til Hizb'allahs lederskab har generalsekretær Nasrallah således udtalt: "Vi mener, at wali alfaqih rent faktisk har ret til at udpege vores ledere, men hvad sagde Khamenei, den $\phi v e r s t e ~ l e d e r, ~ t i l ~ d e t ?$ Han sagde 'Nej, jeres egen konklave skal valge jeres ledere"' (Nasrallah 31.8.1993: 134).

${ }^{20}$ Fadlallah havde blandt andet undervist mange af de bærende kræfter i Hizb'allahs dannelse og opfordret flere mindre organisationer til at gå med i den paraplyorganisation, som Hizb’allah var ved sin dannelse (Se eks. Sankari 2005: 167, 201, Saad-Ghorayeb 2002: 13, Azani 2009: 58-59). 


\footnotetext{
${ }^{21}$ Forholdet var så dårligt, at Fadlallah i de følgende femten år fra hans etablering af sit marjaiyya har Fadlallahs forhold til Iran så dårligt, at han har fraholdte sig fra at rejse til Iran eller mødes med iranske officials til trods for gentagne invitationer (Sankari 2005: 267, Chehabi 2006b: 300).

${ }^{22}$ Se eks. Jaber, 1997:53 for de første år.

${ }^{23}$ På rygtebasis skulle dette ligefrem inkludere organisationens vice-generalsekretær Naim Qassem, der altid har været tæt på Fadlallah og ofte har besøgt hans prædikener.

${ }^{24}$ Meget lidt kendes desværre til Sistanis indflydelse på de libanesiske shiiter, da opmærksomheden i litteraturen herom hidtil har været sparsom. Der mangles således studier, der behandler Sistanis eller hans wakil, stedfortræder, i Libanon, Hamed al-Khalfs, betydning for den shiitiske befolkning i Libanon.
} 